\title{
MINUMAN RUMPUT LAUT DAN MADU DAPAT MENINGKATKAN HAEMOGLOBIN PADA IBU HAMIL
}

\author{
Sri Ayu Arianti $1^{*}$, Sri Lestari², Supriyatni Kartadarma ${ }^{3}$ \\ 1,2 Prodi Kebidanan, Universitas Bhakti kencana \\ ${ }^{3}$ Prodi Kesehatan Masyarakat, Universitas Bhakti kencana \\ *Korespondensi email sri.ayu@bku.ac.id
}

\section{ABSTRACT SEAWEED AND HONEY DRINK CAN INCREASE HAEMOGLOBIN IN PREGNANT WOMEN}

Background : Anemia in pregnancy is currently a global problem in Indonesia because it can cause maternal death. The role of iron is very important for pregnant women and fetuses. The risk of anemia in pregnant women can cause postpartum bleeding, prolonged labor and infection during the puerperium. Disorders of fetal development can also be caused by iron deficiency. The importance of efforts to reduce the problem of anemia in pregnant women can be pharmacologically and non pharmacologically. Non-pharmacological treatment can be know as complementary or alternative therapy by giving seaweed and honey drinks. Consumption of foods containing $\mathrm{Fe}$ such as seaweed and consumption of food containing Fe absorption aids (Fe enhancers) containing vitamin $C$ can increase hemoglobin levels in pregnant women.

Purpose: to determine the effectiveness of seaweed (Eucheuma Spinosum) and honey drinks on increasing haemoglobin levels in pregnant women.

Methods : The research using a quasi-experimental research method with one group pre test-post test design. The sampling technique used was the non-probability sampling technique of "purposive sampling" with a sample of 30 pregnant women who were given 100 grams of seaweed drink and 25 grams of honey a day for 10 days.

Results: The results showed that there was a change in the mean before being given treatment (Pre test) of $10.4 \mathrm{gr} / \mathrm{dl}$ after being given an intervention (post test) of $11.4 \mathrm{gr} / \mathrm{dl}$. Hemoglobin levels after treatment increased on average by $1 \mathrm{~g} / \mathrm{dl}$ with $p$-value $(0.001)(P<0.05)$.

Conclusion : consuming seaweed and honey drinks has an effect on increasing hemoglobin levels in pregnant women.

Sugesstions: from the results of this study can be an alternative in increasing hemoglobin levels in pregnant women

Keywords: Haemoglobin, Seaweed, Honey

\section{ABSTRAK}

Latar Belakang : Anemia pada kehamilan saat ini menjadi masalah global di Indonesia karena dapat mengakibatkan kematian pada ibu. Peranan zat besi sangatlah penting bagi ibu hamil dan janin. Resiko anemia pada ibu hamil dapat menyebabkan terjadinya perdarahan pasca salin, persalinan lama dan infeksi pada masa nifas. Gangguan pada perkembangan janin dapat disebabkan juga karena kekurangan zat besi. Pentingnya dilakukan upaya mengurangi masalah anemia pada ibu hamil dapat secara farmakologi dan non farmakologi. Penanganan secara non farmakologi dapat kita kenal dengan therapi komplementer atau alternatif dengan pemberian minuman rumput laut dan madu. Konsumsi makanan yang mengandung Fe seperti rumput laut dan konsumsi makanan yang mengandung zat pembantu penyerapan $\mathrm{Fe}$ (enhancer $\mathrm{Fe}$ ) yang mengandung vitamin $C$ dapat meningkatkan kadar haemoglobin pada ibu hamil.

Tujuan: penelitian ini bertujuan untuk mengetahui efektifitas minuman rumput laut (Eucheuma Spinosum) dan madu terhadap peningkatan kadar haemoglobin pada ibu hamil.

Metode : penelitian ini menggunakan quasy experiment dengan one group pretest-post test design. Teknik pengambilan sampel dengan teknik Nonprobability sampling jenis "Purposive sampling" dengan jumlah sampel 30 orang ibu hamil yang diberikan minuman rumput laut $100 \mathrm{gr}$ dan $25 \mathrm{gr}$ sehari madu selama 10 hari.

Hasil : Hasil penelitian menunjukkan bahwa terdapat perubahan mean sebelum diberikan perlakuan (Pre test) 10,4 gr/dl setelah di berikan intervensi (post test) 11,4 gr/dl. kadar haemoglobin setelah perlakuan rata-rata meningkat sebesar $1 \mathrm{gr} / \mathrm{dl}$ dengan $\mathrm{p}$-value $(0,001)(P<0,05)$.

Kesimpulan : mengkonsumsi minuman rumput laut dan madu memiliki pengaruh terhadap peningkatan kadar haemoglobin pada ibu hamil. 


\section{JKM (Jurnal Kebidanan Malahayati),Vol 7,No.4.Oktober 2021, ISSN (Print) 2476-8944 ISSN (Online) 2579-762X, Hal 738-743}

hamil

Saran : hasil penelitian ini dapat menjadi salah satu alternatif dalam menaikan kadar hemoglobin pada ibu

Kata kunci: Haemoglobin, rumput laut, madu

\section{PENDAHULUAN}

Kualitas manusia ditentukan oleh kondisi perempuan, karena seorang perempuan mengalami proses kehamilan, persalinan dan menyusui. Salah satu indikator penting dalam menentukan derajat kesehatan ditandai dengan tinggi rendahnya Angka Kematin lbu dan Bayi. (Kemenkes, 2013) Komplikasi anemia pada ibu hamil dapat menyebabkan molahidatidosa, hyperemesis gravidarum, pendarahan antepartum, KPD. Bahaya saat persalinan yaitu kala satu dan dua berlangsung lama.. (Manuaba, 2016) Komplikasi utama 75\% dari kematian ibu adalah pendarahan pasca melahirkan.(Barat, 2017) Anemia dalam kehamilan ketika kadar haemoglobin seorang ibu hamil kurang dari $11 \mathrm{gr} / \mathrm{dl}$. Angka kejadian anemia pada ibu hamil menurut WHO mencapai $42 \%$.(Organization, 2019) Di Indonesia persentase ibu hamil yang mengalami anemia mencapai 37,1\%.(Riskesdas, 2019) Dikabupaten bandung data ibu hamil yang mengalami anemia dari Januari sampai November 2019 terdapat 1.530 ibu hamil yang mengalami anemia.(Riskesdas, 2019)

Penanganan defisiensi zat besi dapat diberikan dengan pengobatan tradisional yang dikenal dengan terapi komplementer. Pengobatan tradisional bukan sekedar sebagai fenomena ekonomi, tetapi lebih luas lagi sebagai fenomena sosial budaya. (Azwar, 2012) Penanggulangan defisiensi zat besi yaitu dengan mengkonsumsi makanan yang mengandung zat besi salah satunya adalah rumput laut. Menurut jurnal Resty didapatkan kenaikan kadar haemoglobin 1,05 gr/dl pada kelompok yang diberikan rumput laut.(Noflidaputri et al., 2018) Uluwiyatun mengatakan ada pengaruh konsumsi rumput laut terhadap peningkatan $\mathrm{Hb}$ dengan $\rho$ value 0,004.(Uluwiyatun et al., 2015) Hasil penelitian Yanti pemberian rumput laut pada ibu menyusui didapatkan $p$ value 0,001.(Yanti \& Aprihatin, 2019) Konsumsi rumput laut berpengaruh terhadap peningkatan kadar haemoglobin pada ibu hamil.(Sherly \& Qurrata, 2021) Mengkombinasikan pisang ambon dengan agar-agar rumput laut dapat meningkatkan kadar haemoglobin dalam jurnal Nancy.(Olii \& Abdul, 2019) Peningkatan hb signifikan pada ibu hamil yang mengkosumsi fe disertai vitamin C. (Agustina, 2019)

Anemia pada ibu hamil disebabkan oleh Kekurangan zat besi untuk pembentukan hemoglobin. Rumput laut memiliki kandungan zat besi, magnesium, natrium, asam amino, vitamin dan mineral yang mencapai 10-20 kali lipat dibanding dengan tanaman darat. Kenaikan kadar haemoglobin akan lebih signifikan apabila dipadukan dengan bahan makanan yang mengandung zat pembantu penyerapan $\mathrm{Fe}$ yaitu vitamin $\mathrm{C}$ seperti madu.

Tujuan penelitian ini untuk mengetahui efektifitas minuman rumput laut (Eucheuma Spinosum) dan madu terhadap peningkatan kadar haemoglobin pada ibu hamil

\section{METODE}

Rancangan penelitian yang digunakan pada penelitian ini adalah Rancangan Eksperimen Semu (Quasi-Experiment). Eksperimen adalah eksperimen yang memiliki perlakuan (treatments), pengukuran-pengukuran dampak (outcome measures), dan unit-unit eksperimen (experimental units). namun tidak menggunakan penempatan secara acak (random assignment) dalam menciptakan pembandingan untuk menyimpulkan adanya perubahan akibat perlakuan.(Azwar, 2012a) Penelitian dilakukan dengan One group pretestpostest design. Populasi dalam penelitian ini adalah keseluruhan objek penelitian atau objek yang teliti. Yang menjadi populasi pada penelitian ini adalah semua ibu hamil yang melakukan pemeriksaan kehamilannya di Puskesmas Cinunuk. Teknik pengambilan sampel pada penelitian ini dengan teknik Nonprobability sampling dengan jenis "Purposive sampling". Sampel dalam penelitian ini sebanyak 30 ibu hamil dengan kriteria inklusi kadar haemoglobin $(\mathrm{Hb})$ kurang dari $11 \mathrm{gr} / \mathrm{dl}$ dan kriteria eksklusi ibu hamil yang mengalami perdarahan ante partum. Teknik penelitian dilakukan dengan melakukan cek kadar $\mathrm{Hb}$ dengan menggunakan alat cek $\mathrm{Hb}$ digital sebelum dan sesudah intervensi yang dilakukan pada 30 orang ibu hamil. Intervensi diberikan berdasarkan penelitian sebelumnya yaitu 100 gram rumput laut (Eucheuma Spinosum) dan 25 gram madu selama 10 hari. Analisa data menggunakan uji wilcoxon.

\section{HASIL DAN PEMBAHASAN Analisis Univariat}

Berdasarkan table 1 karakteristis responden Sebagian besar berusia 20 - 35 tahun 24 orang $(80 \%)$, berpendidikan menengah 28 orang $(93,33 \%)$ dan tidak bekerja 23 orang $(76,66 \%)$. 
Tabel 1.

Distribsi Frekuensi Karakteristik Responden

\begin{tabular}{llcc}
\hline \multicolumn{1}{c}{ Variabel } & \multicolumn{1}{c}{ Kategori } & Jumlah & Prosentase \\
\hline Usia Ibu hamil & $<20$ tahun & 2 & $6,66 \%$ \\
& $20-35$ tahun & 24 & $80 \%$ \\
Pendidikan & $>35$ tahun & 4 & 13,33 \\
& Pendidikan tinggi ( $\geq$ Diploma) & 2 & $6,66 \%$ \\
Pekerjaan & Pendidikan menengah (SMP dan SMA) & 28 & $93,33 \%$ \\
& Bekerja & 7 & $23,33 \%$ \\
& Tidak bekerja & 23 & $76,66 \%$ \\
\hline
\end{tabular}

Tabel 2.

Distribsi Frekuensi haemoglobin sebelum minum rumput laut (Eucheuma Spinosum) dan madu pada ibu hamil di desa cinunuk kabupaten bandung

\begin{tabular}{ccc}
\hline Kategori & $\begin{array}{c}\text { Jumlah } \\
\text { Responden }\end{array}$ & Prosentasi (\%) \\
\hline Naik & 13 & 43.3 \\
Turun & 17 & 56.7 \\
\hline Total & 30 & 100.0 \\
\hline
\end{tabular}

Berdasarkan table 2 mengenai peningkatan hemoglobin sebelum minum rumput laut (Eucheuma Spinosum) dan madu Sebagian besar 13 orang $(43,3 \%)$ naik dan hampir setengahnya 17 orang $(56,7 \%)$ turun.

Tabel 3.

Distribusi Frekuensi Haemoglobin Sesudah Minum Rumput Laut (Eucheuma Spinosum) dan Madu

pada ibu hamil di Desa Cinunuk Kabupaten Bandung

\begin{tabular}{ccc}
\hline Kategori & $\begin{array}{c}\text { Jumlah } \\
\text { Responden }\end{array}$ & Prosentasi (\%) \\
\hline Naik & 23 & 76.7 \\
Turun & 7 & 23.3 \\
\hline Total & 30 & 100.0 \\
\hline
\end{tabular}

Berdasarkan table 3 mengenai peningkatan hemoglobin sesudah minum rumput laut (Eucheuma Spinosum) dan madu Sebagian besar 23 orang $(76,7 \%)$ naik dan sebagian kecil 7 orang $(23,3 \%)$ turun.

\section{Analisis Bivariat}

Berdasarkan tabel 4 dibawah, didapatkan hasil uji wilcoxon tentang nilai Efektifitas Minuman Rumput Laut (Eucheuma Spinosum) dan madu Terhadap Peningkatan Kadar Hemoglobin Pada Ibu Hamil Di Desa Cinunuk Kabupaten Bandung dengan $p$ value $0,001(P<0,05)$ dengan perubahan mean sebelum diberikan perlakuakn (Pre test) 10,4 $\mathrm{gr} / \mathrm{dl}$ setelah di berikan intervensi (post test) 11,4 $\mathrm{gr} / \mathrm{dl}$. Dan selisisih peningkatan HB ibu hamil yaitu $1 \mathrm{gr} / \mathrm{dl}$, sehingga dapat disimpulkan mengkonsumsi rumput laut (Eucheuma Spinosum) dan madu memiliki pengaruh terhadap peningkatan Haemoglobin pada ibu hamil

Tabel 4.

Efektifitas Minuman Rumput Laut (Eucheuma Spinosum) dan madu Terhadap Peningkatan Kadar Hemoglobin

\begin{tabular}{ccc}
\hline Variabel & Mean & P-Value \\
\hline Haemoglobin Pra-tes & 10.4667 & 0,001 \\
Haemoglobin Post-tes & 11.4333 & \\
\hline
\end{tabular}

\section{PEMBAHASAN}

Anemia yang terjadi dalam kehamilan adalah merupakan suatu kondisi ibu hamil dengan kadar haemoglobin kurang dari $11 \mathrm{gr} / \mathrm{dl}$ pada trimester I dan III dan kurang dari 10,5 gr/dl pada trimester II. Hemoglobin di dalam sel darah merah ini memiliki peran untuk mengikat dan mendistribusikan oksigen dari paru-paru ke seluruh tubuh. Hemoglobin juga mengikat dan membawa karbon dioksida dari jaringan tubuh ke paru-paru. Dengan demikian, peningkatan kebutuhan oksigen pada ibu hamil sangat terkait dengan peran hemoglobin. Kondisi haemoglobin $(\mathrm{Hb})$ normal pada ibu hamil akan mendukung ibu hamil untuk bisa memenuhi kebutuhan oksigen janinnya. (Prawirohardjo \& Wiknjosastro, 2017)

Penyebab ibu hamil mengalami anemia antara lain disebabkan oleh kekurangan zat besi. Zat besi merupakan komponen penyusun hemoglobin. Sudah tentu kekurangan zat besi akan memengaruhi nilai $\mathrm{Hb}$ normal ibu hamil. Ibu hamil yang mengalami kekurangan zat besi bisa disebabkan oleh beberapa hal. Kekurangan zat besi pada ibu hamil bisa dikarenakan asupan zat besi yang tidak tercukupi, adanya gangguan pada 


\section{JKM (Jurnal Kebidanan Malahayati),Vol 7,No.4.Oktober 2021, ISSN (Print) 2476-8944 ISSN (Online) 2579-762X, Hal 738-743}

penyerapan zat besi, dan peningkatan kebutuhan zat besi. Penyebab lain dari anemia pada ibu hamil adalah terjadinya pengenceran darah yang terjadi pada usia kehamilan 28- 32 minggu atau dinamakan haemodilusi. Selama masa kehamilan, tubuh ibu hamil akan menyesuaikan diri. Darah ibu hamil akan mengalami pengenceran agar nutrisi bayi bisa tercukupi dan meringankan kerja jantung. Dengan demikian, volume darah ibu hamil akan bertambah. Peningkatan volume darah lebih banyak pada pertambahan plasma darah. Jumlah sel darah merah dan hemoglobin tidak memiliki peningkatan yang seimbang dengan plasma darah. Hal ini membuat konsentrasi sel darah merah di dalam darah menjadi turun. Nilai $\mathrm{Hb}$ pun juga ikut turun. Pengukuran konsentrasi hemoglobin di dalam sel darah merah ini akan terlihat pada nilai $\mathrm{MCHC}$ pada hasil pemeriksaan tes darah rutin atau Complete Blood Count(CBC). Wanita hamil, selama kehamilannya akan mengalami peningkatan plasma darah hingga $30 \%$, sel darah $18 \%$, sedangkan $\mathrm{Hb}$ bertambah $19 \%$. Akibatnya angka kejadian anemia pada kehamilan cukup tinggi. (Irianto, 2014)

Komplikasi anemia pada ibu hamil dapat menyebabkan molahidatidosa, hyperemesis gravidarum, pendarahan antepartum, KPD. Bahaya saat persalinan yaitu kala satu dan dua berlangsung lama. Komplikasi utama $75 \%$ dari kematian ibu adalah pendarahan pasca melahirkan. (Barat,2017). Sedangkan dampak yang dapat timbul pada janin adalah terjadinya gangguan pertumbuhan janin, abortus, kelahiran premature dan berat badan lahir rendah (BBLR). (Manuaba, 2016) Haemoglobin memiliki afinitas (daya gabung) terhadap oksigen dan dengan oksigen itu membentuk oxihemoglobin di dalam sel darah merah. Dengan melalui fungsi ini maka oksigen di bawa dari paru-paru ke jaringan-jaringan tubuh (Syarifuddin, 2013).

Hasil penelitian pre test menunjukkan bahwa hampir setengahnya $17(56,7 \%)$ ibu hamil sebelum diberikan intervensi mengalami penurunan haemoglobin selama kehamilan. Sedangkan post test setelah diberikan intervensi mengkonsumsi rumput laut (Eucheuma Spinosum) 100 gram dan madu 25 gram selama 10 hari sebagian besar 23 orang ibu hamil $(76,7 \%)$ mengalami peningkatan kadar haemoglobin. Hal ini ditunjukkan dalam hasil analisis uji wilcoxon didapatkan hasil $p$ value 0,001 ( $P<0,05)$ dengan perubahan mean sebelum diberikan perlakuakn (Pre test) 10,4 gr/dl setelah di berikan intervensi (post test) 11,4 gr/dl. Dan selisisih peningkatan HB ibu hamil yaitu $1 \mathrm{gr} / \mathrm{dl}$, sehingga dapat disimpulkan mengkonsumsi rumput laut (Eucheuma Spinosum) dan madu memiliki pengaruh terhadap peningkatan Haemoglobin pada ibu hamil.

Penanganan anemia dalam kehamilan ini dapat dilakukan yang pertama dengan mengkonsumsi suplemen zat besi sebanyak 90 tablet selama kehamilan. Kedua memperbaiki asupan gizi ibu dengan mengkonsumsi jenis makanan yang banyak mengandung zat besi seperti rumput laut. Ketiga dengan mengurangi asupan yang menganggu penyerapan zat besi seperti makanan yang mengandung kafein (teh dan kopi), gluten (aneka pasta) dan asam oksalat (peterseli), dan menggantinya dengan konsumsi makanan yang mengandung zat pembantu penyerapan $\mathrm{Fe}$ (enhancer $\mathrm{Fe}$ ) yang mengandung vitamin C seperti madu. Kandungan vitamin C memiliki faktor reduksi yang bermanfaat meningkatkan absorpsi besi dengan mereduksi besi ferri menjadi ferro sehingga absorpsi besi menjadi efisien dan efektif.Vitamin C meningkatkan penyerapan zat besi nonhem sampai empat kali lipatRumput laut adalah merupakan tumbuhan jenis alga spesies ganggang multiseluler golongan devisi thallophyte yang tumbuh di terumbu karang dilaut. Rumput laut merupakan sumber serat makanan yang baik untuk dikonsumsi. Komposisi senyawa organik dari rumput laut (Eucheuma spinosum) antara lain mengandung air $12,90 \%$, protein 5,12 $\%$, lemak $0,13 \%$, karbohidrat $13,38 \%$, serat kasar 1,39 \%, kalsium 52,85 Ppm, zat besi 0,108 Ppm, tembaga 0,768 Ppm, vitamin B1 0,21 mg, vitamin B2 2,26 mg, vitamin C $43 \mathrm{mg}$, dan karaginan 65,75 $\%$. (Poncomulyo,2006) sedangkan kandungan zat dalam madu adalah thiamin (B1), riboflavin (B2), asam askorbat $(\mathrm{C})$, piridoksin (B6), niasin, asam pantotenat, biotin, asam folat, dan vitamin $\mathrm{K}$. (Poncomulyo. T. et al., n.d.)

Berdasarkan social kultural responden yang berusia produktif, berpendidikan menengah dan sebagai ibu rumah tangga memilikii social budaya yang masih kental dengan pengobatan herbal, madu merupakan jenis makanan yang sering digunakan masyarakat sebagai pengobatan herbal. Berdasarkan sosio demografi sebagian wilayah Indonesia dikelilingi lautan dengan karakteristik masyarakat lebih banyak mengkonsumsi tumbuhtumbuhan. Rumput laut yang banyak tumbuh di terumbu karang perairan laut merupakan jenis tanaman laut yang banyak mengadung zat besi 10 20 kali tanaman darat.

Dilihat dari kedua jenis bahan intervensi yaitu rumput laut (Eucheuma spinosum) dan madu keduanya memiliki nilai gizi yang dibutuhkan oleh ibu hamil untuk mencegah anemia yaitu zat besi dan vitamin C. Secara umum dalam 100 gram 
rumput laut mengandung $45 \mathrm{kkal}, 10 \mathrm{gr}$ karbohidrat, $2 \mathrm{gr}$ protein, dan $1 \mathrm{gr}$ lemak. Dengan jumlah tersebut rumput laut dapat memenuhi 14-35 $\%$ kebutuhan harian serat, 27-180\% magnesium, $15-60 \%$ kalsium dan 3-20 \% kebutuhan zat besi. Zat besi yang terkandung dalam rumput laut jika tergabung dengan molekul protein dalam tubuh akan membentuk feririn, Setelah dilakukan absorbsi didalam usus halus akan membentuk transferrin yang berfungsi sebagai transport yang membawa sel darah merah dan oksigen yang dibutuhkan oleh seorang ibu hamil dalam proses kehamilannya. Peningkatan haemoglobin ini didukung juga oleh konsumsi makanan sehari-hari yang mengandung banyak protein. (Almatsier, 2011) Sehingga pada kasus responden yang mengalami penurunan $\mathrm{Hb}$, setelah dilakukan anamnesa lebih jauh adalah responden dengan kategori tingkat konsumsi protein yang kurang.

Hal ini sejalan dengan penelitian yang dilakukan oleh Rifa Rahmi, bahwa rumput laut efektif meningkatkan kadar $\mathrm{Hb}$ dengan $\mathrm{p}$-Value 0,0001. (Rahmi, 2018) Sedangkan peneliti Winda Agustina menyimpulkan bahwa terdapat perbedaan signifikan antara konsumsi tablet Fe dengan dan tanpa vitamin C. (Agustina, 2019). Pada jurnal erpita menunjukkan adanya peningkatan kadar haemoglobin sebesar $1,6 \mathrm{gr} / \mathrm{dl}$ pa ibu menyusui setelah diberikan intervensi rumput laut. (Yanti \& Aprihatin, 2019)

\section{SIMPULAN}

Simpulan dalam penelitian ini menunjukkan bahwa rumput laut (Eucheuma Spinosum) dan madu efektif terhadap peningkatan Haemoglobin pada ibu hamil dengan $p$ value $0,001(P<0,05)$.

\section{SARAN}

Hasil Penelitian Ini Dapat Menjadi Salah Satu Alternatif Dalam Menaikan Kadar Hemoglobin Pada Ibu Hamil

\section{DAFTAR PUSTAKA}

Agustina, W. (2019). Perbandingan Kadar Hemoglobin Pada lbu Hamil Yang Mengkomsumsi Tablet Besi Dengan Dan Tanpa Vitamin C Di Wilayah Kerja Puskesmas Langsa Lama Tahun 2019. Jurnal Nasional Ilmu Kesehatan, 2(2), 7687.

http://journal.unhas.ac.id/index.php/jnik/articl e/view/7080/4347

Almatsier, S. (2011). Prinsip Dasar IImu Gizi. Utama, Gramedia Pusaka, Jakarta.

Azwar. (2012a). Metode Penelitian. Pustaka
Pelajar, Yogyakarta.

Azwar, A. (2012b). Tanaman obat Indonesia. Salemba Medika, Jakarta.

Barat, D. K. P. . (2017). Profil Kesehatan Provinsi Jawa Barat. Dinas Kesehatan Provinsi Jawa Barat.

Irianti, B, Halida, E. M., Duhita, F., Prabandari, F., Yulita,Yulianti, N., Hartiningsih, S. \& Nggraeni, Y. A. (2014). Asuhan Kebidanan Berbasis Bukti. CV Sagung Seto, Jakarta.

Irianto, K. (2014). Gizi Seimbang dalam Kesehatan Reproduksi (Balanced Nutrition in Reproductive Health). ALFABETA, Bandung.

Kemenkes. (2013). Buku Ajar Kesehatan Ibu dan Anak (Mulati, Er). Pusat Pendidikan dan Pelatihan Tenaga Kesehatan, Jakarta Selatan.

Manuaba, I. B. G. (2016). IImu Kebidanan Penyakit dan Kandungan dan KB untuk Pendidikan Bidan. EGC, Jakarta.

Noflidaputri, R., Fort, S., \& Kock Bukittinggi, D. (2018). PERBANDINGAN PEMBERIAN RUMPUT LAUT (EUCHEUMA SP) DAN TABLET FE TERHADAP PENINGKATAN KADAR HEMOGLOBIN IBU HAMIL ANEMIA DI PUSKESMAS. XII(3).

Olii, N., \& Abdul, N. A. (2019). Pisang Ambon Dan Agar-Agar Rumput Laut Terhadap Hemoglobin Ibu Hamil. Jambura Health and Sport Journal, 1(2), 71-81. https://doi.org/10.37311/jhsj.v1i2.2537

Organization, W. . (2019). Maternal Mortality. Www. Who.Int.

Poncomulyo. T., Maryani, H., \& Kristiani, L. (n.d.). Budidaya dan Pengolahan Rumput Laut. Agro Media Pustaka, Surabaya.

Prawirohardjo, S., \& Wiknjosastro. (2017). IImu Kandungan (ketiga). PT Bina Pustaka Sarwono Prawirohardjo, Jakarta.

Rahmi, R. (2018). Efektifitas Konsumsi Rumput Laut Untuk Meningkatkan Kadar Haemoglobin Pada Ibu Hamil Anemia. Jurnal Endurance, $3(1), \quad 195$. https://doi.org/10.22216/jen.v3i1.2616

Rimawati, E. (2010). INTERVENSI SUPLEMEN MAKANAN UNTUK MENINGKATKAN KADAR HEMOGLOBIN PADA IBU HAMIL. Jurnal IImu Kesehatan Masyarakat, 9(3), 161-170. https://doi.org/10.26553/jikm.2018.9.3.161170

Riskesdas. (2019). Laporan Provinsi Jawa Barat. In Lembaga Penerbit Badan Penelitian dan Pengembangan Kesehatan.

Sherly, M., \& Qurrata, D. (2021). PEMBERIAN 
JKM (Jurnal Kebidanan Malahayati),Vol 7,No.4.Oktober 2021,

ISSN (Print) 2476-8944 ISSN (Online) 2579-762X, Hal 738-743

KONSUMSI RUMPUT LAUT (EUCHEUMA SPINOSUM) TERHADAP PENINGKATAN KADAR HEMOGLOBIN PADA IBU HAMIL DIWILAYAH KERJA PUSKESMAS NARAS KOTA PARIAMAN. In Rika Astria R../ Jurnal IImu Keperawatan dan Kebidanan (Vol. 12, Issue 1).
Uluwiyatun, U., Runjati, R., \& Suwondo, A. (2015). Pengaruh Konsumsi Rumput Laut (Eucheuma Sp) terhadap Peningkatan Kadar Hemoglobin dan Status Fe Ibu Hamil Anemia di Kabupaten Pekalongan. Jurnal Kebidanan, 3(7), 8-15.

Yanti, E., \& Aprihatin, Y. (2019). KADAR HEMOGLOBIN PADA IBU MENYUSUI ANEMIA DI PUSKESMAS PARIAMAN. 2(6). 